\title{
WYKAZ DRUKOWANYCH PRAC KS. PROF. MARKA STAROWIEYSKIEGO
}

\section{KSIĄŻKI}

Szymusiak J.M. - Starowieyski M., Słownik wczesnochrześcijańskiego piśmiennictwa, (Starożytna myśl chrześcijańska 2) Poznań 1971, s. 660.

Maria - Eva in traditione Antiochena, Alexandrina et Palaestinensi saeculo $V$

(Excerpta ex dissertatione ad Doctoratum in Facultate Theologiae Pontificiae Universitatis Gregorianae) Roma 1972, ss. 88.

Sobory Kościoła niepodzielonego, cz. 1 - Dzieje, [ $\alpha$ - Teologia dla wszystkich 2], Tarnów 1994, ss. 159.

Łanowski J. - Starowieyski M., Literatura Grecji starożytnej, Warszawa 1996, ss. $264+21$ ilustracji.

Barwny świat apokryfów, Poznań 1998, ss. 46; wyd. nowe i uzupełnione, Poznań 2006, s. 72.

Ze świata wczesnego chrześcijaństwa (Pogadanki radiowe) Pelplin 1998, ss. 340. Słownik wczesnochrześcijańskiego piśmiennictwa Wschodu. Literatury - arabska, armeńska, etiopska, gruzińska, koptyjska, syryjska, Warszawa 1999, s. XIX $+243+21 *+2$ mapy.

Sprawiedliwy z wiary żyje. Życie i męczeństwo Stanisława Starowieyskiego, Kraków 1999, ss. 46.

Starowieyski M. - Silone I., Opowieść o dziwnym księdzu (Don Luigi Orione), Ząbki 1999, ss. 78.

Spotkania i wędrówki, Pelplin 2003, ss. 364.

Czego moga nas nauczyć Ojcowie Pustyni, Kraków 2006, ss. 232.

Judasz - historia, legenda, mity, Poznań 2006, ss. 74.

\section{ARTYKUŁY NAUKOWE}

Kobiety w Eneidzie, „Meander” 21 (1966) 290-309.

Izydor z Sewilli (560-636) „Meander” 22 (1967) 452-466. 
Polski przekład trawestacji Blumauera, „Meander” 23 (1968) 91-100. Dzieciństwo Pana, tzw. Ewangelia Tomasza, AnCra 4 (1972) 315-358.

Świętość w życiu i myślach pustelników egipskich IV wieku, w: Błogosławiony Maksymilian wśród nas (W nurcie zagadnień posoborowych 6), red. B. Bejze, Warszawa 1972, 367-378.

Eneasz z Gazy i jego listy, „Meander” 28 (1973) 1-22, 93-108.

Kolędy makaroniczne, „Meander” 29 (1974) 50-53.

Obraz literatury klasycznej pogańskiej w dziełach Izydora z Sewilli, „Meander”

29 (1974) 357-367; 30 (1975) 19-35.

Problem apokryfów, „Summarium” 1975, nr 4 (24) 131-133.

Mariologia św. Atanazego, RTK 23 (1976) z. 4, 109-132.

Apokryficzna korespondencja króla Abgara z Chrystusem, STV 15 (1977) nr 2, 177-200.

Ewangelie apokryficzne, „Znak” 29 (1977) nr 5, 522-530.

Itinerarium Egeriae, „Meander” 33 (1978) 93-108, 234-245.

Łacina w wypowiedziach Stolicy Apostolskiej w ostatnim czterdziestoleciu, „Meander” 34 (1979) 191-196.

Czytania patrystyczne w nowej „Liturgii godzin”, STV 18 (1980) nr 2, 241-251. Les problèmes de systematisation et d'interprétation des évangiles apocryphes, StPatr 17,2 (1982) 731-737.

Początki monastycyzmu zachodniego, w: Księga Pamiątkowa 300-lecia Metropolitalnego Seminarium Duchownego w Warszawie, Warszawa 1982, 262287, [= WST 1 (1983) 258-283].

Starożytni chrześcijanie wobec otaczającego ich świata, w: Odpowiedzialni za świat (Powołanie człowieka 5), red. L. Balter, Poznań 1982, 34-70.

La penitencia en los apotegmas de los Padres de Desierto, w: Reconciliacion y penitencia, Pamplona 1983, 283-289.

Les apocryphes chez les écrivains du IV siècle, w: Miscellanea Historiae ecclesiasticae, t. 6, Bruxelles - Warszawa 1983, 132-141.

Apoftegmaty Ojców Pustyni, „Zagadnienia Rodzajów Literackich” 27 (1984) z. $1,121-124$.

La esperanza (elpis, elpizo) en los Padres Apostolicos, w: Dios y Hombre, Pamplona 1984, 747-750.

La pénitence dans les apophtegmes des Pères du désert, VoxP 4 (1984) z. 6-7, 317-326.

Ojcowie o pokucie, WAW 74 (1984) nr 5-6, 167-184.

Reguła zakonna, „Zagadnienia Rodzajów Literackich” 27 (1984) z. 1, 130-132. Tytut „Theotokos” w świadectwach przedefeskich, AnCra 16 (1984) 409-449.

Pisarze pogańscy o chrześcijanach, PP 102 (1985) nr 1, 18-30; 102 (1985) nr 2, 181-194; 102 (1985) nr 3, 343-357.

Powstanie święta Bożego Narodzenia, „Królowa Apostołów” 49 (1985) nr 12, 4-5. 
Eucharystia pierwszych chrześcijan, w: II Kongres eucharystyczny w Polsce, t. 1, Warszawa 1986, 73-88 [= TP 41 (1987) nr 22, 1-2].

Mariologia Orygenesa, w: Orygenes, Homilie o Ewangelii św. Łukasza (PSP 36), Warszawa 1986, 5-29.

Patrologia $w$ seminariach polskich (uwagi patrologa) VoxP 6 (1986) z. 11, 659-665.

L'enseignement de patrologie dans les seminaires polonais, „Bulletin St. Sulpice" 13 (1987) 56-61.

L'ésperance chez les Pères Apostoliques, VoxP 7 (1987) z. 12-13, 371-381.

Maryja w pierwszych wiekach Kościoła, ,W drodze” 16 (1988) nr 7, 3-13; 17 (1989) nr 5, 21-28 [= „Immaculata” nr 285-286 (1988) 40-54; 297-298 (1989) 21-28].

Najstarszy opis mariofanii, VoxP 8 (1988) z. 15, 735-744.

Formacja kulturowa przyszłych kapłanów, AK 81 (1989) t. 112, z. 2, 393-406.

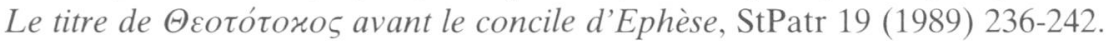

Papieski Wydziat Teologiczny w Warszawie, VoxP 9 (1989) z. 16, 387-388.

Remarques sur les sources de quelques apophtegmes des Péres du Désert, StPatr 18,2 (1989) 293-298.

Wykorzystanie pomocy dydaktycznych w nauczaniu patrologii, VoxP 6 (1989) z. 16, 287-300.

Egzegeza Ojców Kościoła, AK 82 (1990) t. 115, z. 1, 25-36.

Hymn liturgiczny na tle rozwoju poezji starochrześcijańskiej, „Classica Wratislaviensia” 13 (1990) 145-161.

„Księga Eklezjastesa” w starożytności chrześcijańskiej, VoxP 10 (1990) z. 19, 317-326.

La plus ancienne description d'une mariophanie par Gregoire de Nysse, w: Studien zu Gregor von Nyssa und der christliche Spätantike, ed. H.R. Drobner - C. Klock, Leiden 1990, 245-253.

Le origini della poesia cristiana, „AION” (Napoli) 12 (1990) 237-255.

Omiletica mariana palestinese nel secolo $V$, w: La mariologia nella catechesi dei Padri, t. 2, Roma 1990, 117-128.

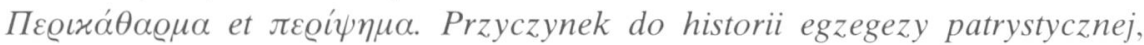
„Eos” 78 (1990) 281-295.

Sobory w starożytności chrześcijańskiej (1). Kościót przedsoborowy, „W drodze" 18 (1990) nr 1, 7-14.

Sobory w starożytności chrześcijańskiej (2). Sobór Nicejski I, „W drodze” 18 (1990) $\mathrm{nr}$ 2, 64-73.

Sobory w starożytności chrześcijańskiej (3). Konstantynopol I, „W drodze” 18 (1990) $\mathrm{nr}$ 3, 72-81.

Sobory w starożytności chrześcijańskiej (4). Sobór Efeski 431 rok, „W drodze” 18 (1990) $\mathrm{nr} 4,64-74$.

Sobory w starożytności chrześcijańskiej (5). Sobór Chalcedoński, 451 rok, „W drodze" 18 (1990) nr 5, 63-73. 
Sobory w starożytności chrześcijańskiej (6). Sobór Konstantynopolitański II,

553 rok, ,W drodze” 18 (1990) nr 6, 74-84.

Sobory w starożytności chrześcijańskiej (7). Sobór Konstantynopolitański III (680/681), „W drodze” 18 (1990) nr 7, 81-92.

Sobory w starożytności chrześcijańskiej (8). Sobór Konstantynopolitański IV (869/870) rok, „W drodze” 18 (1990) nr 8, 69-78.

Synod w Elwirze (306) wstęp, oprac. - M. Starowieyski; przekład kanonów -

M. Rola, WST 3 (1985-1990) 183-204.

Epigramy. Św. Grzegorz z Nazjanzu, tłum. J. Łanowski, oprac. M. Starowieyski, WST 5 (1991) 25-63.

Eucharystia w starożytnym chrześcijaństwie. Zestawienie topo-bibliograficzne,

WST 4 (1991) 42-112.

Grzegorz z Nazjanzu, Wybór epigramów, tłum. J. Łanowski, wstęp i komentarz

M. Starowieyski, WST 4 (1991) 149-158.

Narodziny poezji chrześcijańskiej, „Bobolanum” 2 (1991) 99-110.

Problem apokryfów u pisarzy IV wieku, „Meander” 11-12 (1991) 495-501.

Św. Barnaba w historii i legendzie, AnCra 23 (1991) 392-413.

Aborcja w opinii wczesnochrześcijańskich pisarzy, PP 109 (1992) nr 11, 292-307. Jakub Większy, Apostot, „W drodze” 20 (1992) z. 8, 68-76.

Isidore de Séville et les apocryphes, w: De Tertullien aux Mozarabes. Mélanges J. Fontaine, vol. 1, Paris 1992, 133-139.

Aborcja w oczach wczesnochrześcijańskich pisarzy, „Studia Paradyskie” 3 (1993) 107-128.

Catechesi biblica dei pellegrini in Terra Santa (secoli II-IV) w: Esegesi e catechesi nei Padri (secolo II-IV) (Biblioteca di Scienze Religiose 106), a cura di S. Felici, Roma 1993, 147-161.

Datowanie Aktów św. Barnaby (BHG 225; ClAp 385) i Panegiryku św. Barnaby (BHG 226; CPG 7400; ClAp 286), „Meander” 48 (1993) 319-323.

Les écrivains paiens et les chrétiens au II siècle, StPatr 26 (1993) 184-191.

Le livre de l'Ecclésiaste dans l'antiquité chrétienne, w: Gregory of Nyssa, Homiles on Ecclesiastes (Proceedings of the Seventh International Colloquium on Gregory of Nyssa), ed. S.G. Hall, Berlin 1993, 405-440.

Maryja w Kościele starożytnym, w: Matka Jezusa pośród pielgrzymującego Kościoła, red. J.S. Gajek - K. Pęk, Warszawa 1993, 77-106.

Pielgrzymki do Ziemi Ś więtej w wiekach II-IV a Biblia, „Bobolanum” 4 (1993) 146-160.

Recepcja literatury wczesnochrześcijańskiej w Polsce, „Literatura na Świecie”, 1993, nr 12 (269), 265-280.

Datation des Actes (Voyages) de S. Barnabé (BHG 225, ClAp 385) et du Panégérique de S. Barnabé d'Alexandre le Moine (BHG 226, CPG 7400, ClAp 286) w: Philohistor. Miscellanea in honorem Caroli Laga Septuagenarii, ed. A. Schoors - P. van Deun, Leuven 1994, 193-198. 
Dzieje świętego Apostoła i Ewangelisty Jana Teologa, spisane przez jego ucznia Prochora, „Studia Paradyskie” 4 (1994) 131-202.

Izydor z Sewilli i apokryfy, w: „Acta Universitatis Nicolai Copernici. Historia” 1994, nr 271, Toruń 1994, 151-157.

Les apocryphes dans la tragédie Christus Patiens, „Apocrypha” 5 (1994) 269288.

Les „De viris illustribus” comme sources pour l'histoire de la littérature chrétienne ancienne, „Pomoerium. Studia et commentarii ad orbem classicum spectantia” 1 (1994) 127-138.

Św. Marcin i jego biograf, „W drodze” 22 (1994) nr 11, 63-74.

Świętego Marcina chwała pośmiertna, „W drodze” 22 (1994) nr 12, 74-82.

Évolution des structures monastiques: des ascètes aux ordres religieux, w: La vie quotidienne des moines e des chanoines réguliers au Moyen-Age et temps modernes, red. M. Derwich, Wrocław 1995, 99-109.

Kobieta w starożytności chrześcijańskiej, w: Kobieta w kulturze średniowiecznej

Europy. Księga Pamiątkowa A. Karłowskiej Kamzowej, red. A. Gąsiorowski, Poznań 1995, 23-39 [= „W drodze” 23 (1995) nr 3, 17-31].

Legenda św. Jakuba Większego Apostoła, WST 8 (1995) 39-96.

Pielgrzymka Egerii, w: Peregrinationes, Pielgrzymki w kulturze dawnej Europy,

red. H. Manikowska - H. Zaremska, Warszawa 1995, 89-97.

Sobór Efeski i sprawa Nestoriusza - problem źródeł, „Meander” 50 (1995) 23-35.

Żywoty $i$ spisy Apostołów. Materiaty do poznania legendy i kultu Apostołów, „Bobolanum” 6 (1995) 132-154.

La légende de saint Jacques le Majeur, „Apocrypha” 7 (1996) 193-203.

Materiały do poznania legendy i kultu Apostołów (2): Grzegorz z Tours, Księga

o cudach błogosławionego Andrzeja Apostoła, WST 9 (1996) 49-74.

Od ascetów do zakonów, „W drodze” 24 (1996) nr 4, 31-39.

Przygotowanie do kapłaństwa w Hiszpanii wizygockiej, VoxP 13-15 (19931996) z. 24-29, 276-283.

Apokryfy jako utwory apologetyczne, WST 10 (1997) 357-366.

Caelestis Urbs Hierusalem, w: Jerozolima w kulturze europejskiej, red. P. Paszkiewicz - T. Zadrożny, Warszawa 1997, 49-57.

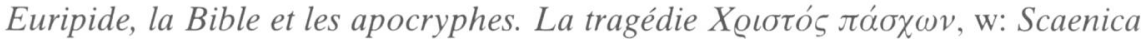

Saravi-Varsoviensia. Beiträge zum antiken Theater und seinem Nachleben, hrsg. J. Axer - W. Görler, Warszawa 1997, 143-157.

Legenda o powstaniu Sktadu Apostolskiego, w: Symbol Apostolski w nauczaniu i sztuce Kościoła do Soboru Trydenckiego, red. R. Knapiński, Lublin 1997, 51-62.

Patrologia w Polsce (1945-1997), AnCra 29 (1997) t. 29, 337-348.

Quelques remarques sur la méthode apocryphe, StPatr 30 (1997) 102-113.

Scena ,Quo vadis” (Acta Petri, Martyrium 6), VoxP 17 (1997) z. 32-33, 381-390. 
Sobór Efeski i sprawa Nestoriusza - problem źródet, w: Maryja w tajemnicy Chrystusa, red. S.C. Napiórkowski - S. Longosz, Niepokalanów 1997, $11-27$.

Eléments apologétiques dans les apocryphes, w: Les apologistes chrétiens et la culture grecque, réd. B. Pouderon - J. Doré, ThH 105, Paris 1998, 187-197. Humanizacja i dehumanizacja teologii, „W drodze” 26 (1998) nr 5, 53-65.

Klimek P. - Starowieyski M., Commentari patristici ai libri del Antico Testamento (I) Commentari patristici ai libri dei Profeti Maggiori, w: Mélanges d'histoire Byzantine offerts à Oktawiusz Jurewicz à l'occasion de son soixante-dixième anniversaire, Łódź 1998, 10-28.

L'épisode Quo vadis? (Acta Petri, Martyrium 6), „Humanitas” (Coimbra) 50 (1998) 257-262.

Le travail patrologique: traductions, commentaires, études, w: Théologie en Pologne aujourd'hui, dir. H. Bourgeois, Paris 1998, 74-79.

Materiaty do poznania legendy i kultu Apostotów (3): Teksty o św. Andrzeju Apostole, WST 11 (1998) 125-152.

Professore Ottavio Jurewicz (+ bibliografia), w: Mélanges d'histoire Byzantine offerts à Oktawiusz Jurewicz à l'occasion de son soixante-dixième anniversaire, Łódź 1998, 3-9.

Bóg działa przez wszystkich kapłanów (teksty patrystyczne), „Pastores” 2 (1999) nr 1, 122-131.

Kobieta w starożytności chrześcijańskiej, w: Kobieta w kulturze średniowiecznej Europy, Poznań 1999², 23-39.

Komentarze biblijne patrystyczne w „De viris illustribus” św. Hieronima, WST 12 (1999) 205-216.

Od legendy do historii - święte założycielki Kościołów Gruzji i Armenii, w: Kobieta w starożytności chrześcijańskiej, SACh 14, Warszawa 1999, 20-31. Uwagi o patrologii w Polsce, VoxP 19 (1999) t. 36-37, 11-20.

Rodzące się chrześcijaństwo wobec filozofii, w: Inspiracje platońskie w literaturze staropolskiej, red. A. Nowicka-Jeżowa - T. Stępień, Warszawa 2000, $15-32$.

Ananiasz z Sirakaci (ok. 600-670) i jego autobiografia, w: Ars Graeca - Ars Latina. Studia dedykowane profesor A. Różyckiej Bryzek, Kraków 2001, $67-74$.

Autobiografia i elementy autobiograficzne $w$ literaturze wczesnochrześcijańskiej, WST 14 (2001) 115-130.

Autobiografia w starożytności chrześcijańskiej, w: Autobiografizm-przemiany, formy, znaczenia, red. H. Gosk - A. Zieniewicz, Warszawa 2001, 57-68.

Kulturotwórcza rola apokryfów, w: Idee chrześcijańskie w życiu Europejczyka, red. A. Ceglińska - Z. Staszewska, Łódź 2001, 63-76.

Les commentaires bibliques patristiques dans le „De viris illustribus” de S. Jérôme, StPatr 34 (2001) 459-469. 
Ks. prof. Bilczewski-uczony, WST 15 (2002) 141-156.

Męczeństwo św. Apostoła i Ewangelisty Marka w Aleksandrii,w: Ad sapientiam cordis. Księga Pamiątkowa dedykowana ks. prof. L. Gładyszewskiemu, red. P. Podeszwa - W. Szczerbiński, Gniezno 2002, 177-185. Bilan des études patristiques en Pologne, CPE 2002, nr 85, 50-58.

Stanula Emil, w: Polski Słownik Bibliograficzny, t. 42, Kraków 2003-2004, 337-338.

Studia z dziedziny historii literatury wczesnochrześcijańskiej i patrologii w Polsce. Próba oceny sytuacji, „Meander” 58 (2003) 163-170.

Alcune osservazioni sulla struttura letteraria degli atti degli apostoli apocrifi, w: Aegyptus Christiana. Mélanges d'hagiographie égyptienne et orientale dédiés à la mémoire du P. Paul Devos, Bollandiste, cur. U. Zanetti E. Lucchesi, Cahiers d'Orientalisme 25, Genève 2004, 19-28.

Autobiografie męczenników afrykańskich w III wieku, w: Męczennicy w świecie późnego antyku, Sympozja Kazimierskie IV, Lublin 2004, 111-126.

L'Autobiographie dans l'antiquité chrétienne, w: Chartae charitatis. Études patristiques et d'antiquité tardive en hommage à Yves-Marie Duval, ed. B. Gain - P. Jay - G. Nauroy, Paris 2004, 37-54.

L'épisode 'Quo vadis?', w: Philomathestatos. Studies in Greek and Byzantine Texts presented to Jacques Noret for his Sixty-Fifth Birthday, ed. B. Janssens - B. Roosen - P. van Deum, Leuven 2004, 591-601.

Teksty do poznania legendy Judasza. Materiaty do poznania legendy i kultu Apostołów (4), WST 17 (2004) 65-88.

Literatura Grecji starożytnej, t. 2, red. H. Podbielski, Lublin 2005, 919-926 (Grecka literatura chrześcijańska, Wprowadzenie [z S. Longoszem]); 957-963 (Apokryfy Nowego Testamentu); 1027-1037 (Poezja chrześcijańska); 1115-1126 (Literatura monastyczna).

Roman Melodos, w: Euterpe, Terpsichore, Erato. Liryka grecka i jej recepcja. Księga Pamiątkowa Alicji Szastyńskiej-Siemion w 70. rocznicę urodzin, Classica Wratislaviensia 26, Wrocław 2005, 209-219.

Stosunki papieża Grzegorza Wielkiego z Kościołami Wschodu, „Teologia Patrystyczna" 2 (2005) 33-46.

Eucaristia dei primi cristiani, w: Congregazione per il Culto Divino e la Disciplina dei Sacramenti, Redemptionis Sacramentum, L'Eucaristia, azione di Cristo e della Chiesa, Siena 2006, 91-106.

Les témoins de Dieu. Les moines de l'Antiquité tardive et l'evangelisation, w; Saggi di storia della cristianizzazione antica e altomedievale, a cura di B. Luiselli, Roma 2006, 147-177. 


\section{WSTĘPY, KOMENTARZE, WYBÓR TEKSTÓW, OPRACOWANIA REDAKCYJNE I MERYTORYCZNE}

Karmię was tym, czym sam żyję. Ojcowie Kościoła komentują ewangelie niedzielne, Rok A, oprac. M. Starowieyski, przedmowa kard. G.M. Garrone, posłowie W. Wojdecki, OŻ 1, Kraków 1978 (wyd. 2, Warszawa 1984; wyd. 3, Warszawa 2001).

Karmię was tym, czym sam żyję. Ojcowie Kościoła komentują ewangelie niedzielne, Rok B, oprac. M. Starowieyski, OŻ 2, Kraków 1979 (wyd. 2, Warszawa 1984; wyd. 3, Warszawa 1999).

Karmię was tym, czym sam żyję. Ojcowie Kościoła komentuja ewangelie niedzielne, Rok C, oprac. M. Starowieyski, OŻ 3, Kraków 1980 (wyd. 2, Warszawa 1984; wyd. 3, Warszawa 2000).

Apokryfy Nowego Testamentu, t. 1, cz. 1-2: Ewangelie, oprac. M. Starowieyski, Lublin 1980 (wyd. 2, Lublin 1986; wyd. 3 nowe, Kraków 2003).

I Padri vivi. Commentari patristici al Vangelo domenicale, Anno A, Roma 1980. I Padri vivi. Commentari patristici al Vangelo domenicale, Anno B, Roma 1980. I Padri vivi. Commentari patristici al Vangelo domenicale, Anno C, Roma 1980. Starożytne reguły zakonne, wybór, wstępy, oprac., niektóre przekłady M. Starowieyski, PSP 26, Warszawa 1981.

I Padri vivi. Commentari patristici al Vangelo domenicale, Solennità e feste, Roma 1982 (wyd. 2, Roma 1986).

Karmię was tym, czym sam żyję. Ojcowie Kościoła prowadza przez święta roku kościelnego. Święta, wybór i oprac. M. Starowieyski, komentarze liturgiczne J. Miazek, OŻ 4, Kraków 1982 (wyd. 2, Warszawa 1984).

Księga starców, tłum. M. Borkowska, wstęp i oprac. M. Starowieyski, OŻ 5, Kraków 1983.

Muza chrześcijańska, t. 1: Poezja armeńska, syryjska, etiopska, wstęp M. Starowieyski - A. Mandalian - W. Myszor, posłowie J. Reczek, oprac. M. Starowieyski, OŻ 6, Kraków 1985.

Apoftegmaty Ojców Pustyni, tłum. M. Borkowska - M. Starowieyski M. Rymuza, wstępy E. Makowiecka - M. Starowieyski - E. Wipszycka, oprac. M. Starowieyski, PSP 33, z. 1-2, Warszawa 1986.

Eucharystia pierwszych chrześcijan. Ojcowie Kościoła nauczają o Eucharystii, oprac. M. Starowieyski, wstęp M. Starowieyski - J. Miazek - A. Luft, OŻ 7, Kraków 1987 (wyd. 2 poprawione, Kraków 1997, zob. niżej).

Pierwsi świadkowie. Wybór najstarszych pism chrześcijańskich, tłum. A. Świderkówna, oprac. M. Starowieyski, OŻ 8, Kraków 1988.

J. Karczewska, Wyposażenie światyni katolickiej Niepokalanego poczęcia NMP w Puri (Indie), wstęp, komentarz M. Starowieyski, Pieniężno 1989.

Męczennicy, wstęp, oprac. E. Wipszycka - M. Starowieyski, OŻ 9, Kraków 1990. 
Verbraken P.P. - Starowieyski M., Ojcowie Kościoła. Panorama patrystyczna, Teksty francuskie przełożyli M. Starowieyski i S. Kawecki, Warszawa 1990. Św. Jan Chryzostom, Dialog o kapłaństwie, tłum. W. Kania, wstęp H. de Lubac - M. Starowieyski, oprac. M. Starowieyski, Kraków 1992.

Muza chrześcijańska, t. 2: Poezja łacińska starożytna i średniowieczna, wstęp i oprac. M. Starowieyski, OŻ 10, Kraków 1992.

Pierwsza Księga Starców - Gerontikon, tłum. M. Borkowska, wstęp i oprac. M. Starowieyski, BOK 2, Kraków 1993.

Św. Jan Chryzostom, Katechezy chrzcielne (Homilie katechetyczne dla tych, którzy mają być oświeceni oraz dla neofitów 1-8), thum. W. Kania, wstęp i oprac. M. Starowieyski, U źródeł katechumenatu 1, Lublin 1993.

Żywoty Ojców Jurajskich, przekład zbiorowy: D. Gacka - M. Poszepczyńska A. Stachowicz - K. Tomaszuk - I. Żółtowska, pod kierunkiem J.A. Wojtczaka, oprac. i red. M. Starowieyski, ŹM 1, Kraków 1993.

Cezary z Arles, Pisma monastyczne, tłum. E. Czerny - M. Borkowska - J. Piłat, wstęp. J. Piłat, red. M. Starowieyski, ŹM 2, Kraków 1994.

Paweł Biskup Monembasii, Opowiadania dla duszy pożyteczne o cnotliwych i bogobojnych męzach i niewiastach, tłum. i oprac. M. Starowieyski, MBOK 1, Kraków 1994.

Św. Jan Chryzostom, Katechezy chrzcielne (homilie katechetyczne dla tych, którzy mają otrzymać chrzest [zostać oświeceni] oraz dla neofitów 9-12), tłum. W. Kania, wstęp i oprac. M. Starowieyski, U źródeł katechumenatu 2, Lublin 1994. Wczesne reguty monastyczne Galii, tłum. K. Bielawski, wstęp J. Piłat, red.

M. Starowieyski, ŹM 3, Kraków 1994.

Anonim (przypisywany św. Grzegorzowi z Nazjanzu) Chrystus cierpiący. Pierwszy chrześcijański dramat, tłum. J. Łanowski, wstęp i oprac. M. Starowieyski, BOK 5, Kraków 1995.

Droga krzyżowa z Ojcami Kościoła, teksty: S. Kawecki - J. Naumowicz M. Starowieyski, red. M. Starowieyski, Częstochowa 1995.

Duchowość starożytnego monastycyzmu. Materiały z międzynarodowej sesji naukowej Kraków - Tyniec, 16-19 listopada 1994, Wykłady otwarte, red. M. Starowieyski, Kraków 1995.

Dwunastu; Pseudo-Abdiasza Historie apostolskie, tłum. E. Nowak - M. Starowieyski, wstęp M. Starowieyski - S. Wronka, oprac. M. Starowieyski, OŻ 11, Kraków 1995.

Muza chrześcijańska, t. 3: Poezja grecka od II do XV wieku, wstęp i oprac. M. Starowieyski, OŻ 12, Kraków 1995.

I Padri vivi, vol. 1-4, w: La Bibbia e i Padri della Chiesa, Padova 1995, wydanie na płycie CD-ROM.

Sulpicjusz Sewer, Pisma o św. Marcinie z Tours: Żywot, Listy, Dialogi, tłum. P.J. Nowak, wstęp, komentarz i oprac. M. Starowieyski, posłowie H. Malewska, ŹM 8, Kraków 1995. 
The Spirituality of Ancient Monasticism. Acts of the International Colloquium held in Cracow - Tyniec 16-19 $9^{\text {th }}$ November 1994, Specialized Contributions, ed. by M. Starowieyski, Cracow 1995.

Do Ziemi Świętej. Najstarsze opisy pielgrzymek do Ziemi Świętej (IV-VIII wiek), wybór, wstęp, wprowadzenie i oprac. P. Iwaszkiewicz, przedmowa M. Starowieyski, OŻ 13, Kraków 1996.

Druga Księga starców - Verba seniorum, tłum. M. Kozera, wstęp i oprac. M. Starowieyski - L. Regnault, oprac. M. Starowieyski, BOK [nie oznaczono numeru w serii], Kraków 1996.

Pachomiana Latina, tłum. A. Bober - W. Miliszkiwicz - M. Starowieyski, wstęp V. Desprez, oprac. M. Starowieyski, ŹM 11, Kraków 1996.

Palladiusz, Opowiadania dla Lausosa (Historia Lausiaca), tłum. S. Kalinkowski, wstęp i oprac. M. Starowieyski, ŹM 12, Kraków 1996.

Eucharystia pierwszych chrześcijan. Ojcowie Kościoła nauczają o Eucharystii, oprac. M. Starowieyski, wstęp M. Starowieyski - J. Miazek - A. Luft, wyd. 2 poprawione, BOK [nie oznaczono numeru w serii], Kraków 1997.

Regnault L., Ewangelia przeżyta na pustyni, red. naukowa M. Starowieyski, Kraków 1997.

Nerses Šnorhali, Jezus, Syn jedyny Ojca i inne poematy, wstęp i oprac.

M. Starowieyski, OŻ 14, Kraków 1998.

Pierwsi świadkowie. Pisma Ojców Apostolskich, przekład A. Świderkówna, wstęp, komentarz i oprac. M. Starowieyski, wyd. 2 popr. i uzupełnione, BOK 10, Kraków 1998.

Regnault L., Słowo Ojców Pustyni na dzień dzisiejszy: Apoftegmaty Ojców przełożone i skomentowane, tłum. J. Kokowska, red. naukowa, M. Starowieyski, Kraków 1998.

Regnault L., Wstuchując się dziś w słowa Ojców Pustyni, tłum. J. Kokowska, red. naukowa M. Starowieyski, Kraków 1998.

Desprez V., Początki monastycyzmu. Dzieje monastycyzmu chrześcijańskiego do Soboru Efeskiego (431), t. 1-2, przedmowa P. Miquel, przekład J. Dembska, red. nauk. M. Starowieyski, ŹM 21-22, Kraków 1999.

Vannier J.M., Bóg Ojciec - tajemnica Miłości. Ojcowie Kościoła o Bogu Ojcu, red. M. Starowieyski - J. Naumowicz, Warszawa 1999.

Vannier J. M., Trójca Święta - tajemnica jedności. Teksty z tradycji, red. J. Naumowicz - M. Starowieyski, Warszawa 2000.

Grzegorz Wielki, Dialogi, tłum. E. Czerny - A. Świderkówna, wstęp A. de

Vogüé, komentarz i oprac. M. Starowieyski, ŹM 23, Kraków 2000.

Apokryfy Nowego Testamentu, t. 3: Listy i Apokalipsy chrześcijańskie, red.

M. Starowieyski, Kraków 2001.

Grzegorz Wielki, Księga Reguty pasterskiej, tłum. E. Szwarcenberg-Czerny, wstęp i oprac. M. Starowieyski, ŹM 30, Kraków 2003. 
Ojcowie Kościoła Wschodniego o Eucharystii, oprac. M. Starowieyski, Katowice - Ząbki 2005.

Ojcowie Kościoła Zachodniego o Eucharystii, oprac. M. Starowieyski, Katowice - Ząbki 2005.

Muza łacińska. Antologia poezji wczesnochrześcijańskiej i średniowiecznej (III-XV w.), oprac. M. Starowieyski, BN II 255, Wrocław-Warszawa 2007. Apokryfy Nowego Testamentu, t. 2, cz. 1-2: Dzieje Apostolskie, oprac. M. Starowieyski, Kraków 2007.

\section{HASŁA W ENCYKLOPEDIACH, SŁOWNIKACH}

Słownik pisarzy antycznych, red. A. Świderkówna, (recenzent literatury chrześcijańskiej M. Starowieyski) Warszawa 1982, hasła: Amphilochios, s. 60; Apokryfy, s. 71-72; Basileios ( $z$ Seleucji), s. 114; Benedictus Cassinensis, s. 115-116, Caesarius Arelatensis, s. 124; Catenae, s. 129; Didymos (Ślepy), s. 162; Egeria, s. 173; Eudokia, s. 187; Eusebius Vercellensis, s. 197; Faustus, s. 199; Ferrandus, s. 200; Fulgentius Ruspensis, s. 205; Gregorios-Theodoros Thaumaturgos, s. 218; Gregorius (z Elwiry) s. 218; Hesychios (z Jerozolimy), s. 235; Isidoros (z Peluzjum), s. 255-256.; Itineraria, s. 258-259.; Iulianus ( $z$ Aeclanum), s. 259; Leontios ( $z$ Bizancjum), s. 285; Maximus Turinensis, s. 311; Nemesios (z Emesy), s. 324; Nestorios, s. 326; Novatianus, s. 330; Optatus (z Milewe), s. 332; Pacianus, s. 339; Pelagius, s. 350; Petrus Chrysologus, s. 354; Priscillianus, s. 388; Prokopios $z$ Gazy, s. 391; Romanos ho Melodos, s. 402; Rufinus, s. 403-404; Severos (z Antiochii), s. 417; Theodoros (Lektor), s. 453.

Eteria, w: EK IV, Lublin 1983, 1161-1162.

Encyklopedia kultury bizantyńskiej, red. O. Jurewicz, Warszawa 2002, hasła: Amfiloch z Ikonium, s. 22; Andrzej, s. 33; Apoftegmaty Ojców Pustyni, s. 41-42; Apokryfy, s. 42-43; Apostołowie, s. 46; Blachernitissa, s. 102; Diodor z Tarsu, s. 145; Eneasz z Gazy, s. 159; Epifania, s. 160; Euzebiusz z Cezarei, s. 170; Gelazy z Cezarei, s. 185; Grzegorz Cudotwórca, s. 191; Grzegorz z Cypru, s. 191; Grzegorz z Nyssy, s. 192; Jan II (bp. Jerozolimy), s. 227; Jan Chryzostom, s. 228; Jan Klimaks, s. 231; Jan z Egei, s. 239; Jan ze Scytopolis, s. 240; Jana Chryzostoma św. liturgia, s. 240; Józef Hymnograf, s. 245; Julian z Halikarnasu, s. 246; Kapadoccy Ojcowie, s. 255; Kyros, s. 297; Leoncjusz z Bizancjum, s. 309; Lucifer z Calaris, s. 314; Eazarz Stylita, s. 316; Łukasz Stylita, s. 317; Martyrium, s. 332; Martyrologium, s. 332; Maryja, s. 332-333; Męczennik, s. 341-342; Modest, s. 354; Monoteletyzm, s. 356; Montanizm, s. 357; Monte Cassino, s. 357; Ojcowie Kościoła, s. 379-380; Proklos, s. 411; Qalat Seman, s. 418; Sergiusz, s. 434-435; Sisinios, s. 436; Sisinios I, s. 436; Sisinios II, s. 436; Symeon Stylita Młodszy, s. 448; Talasjusz, s. 453. 
Nuovo Dizionario Patristico e di Antichità Cristiane, vol. 1-2 (A-O), red. A. Di Berardino, Casale Monferrato 2006, hasła: Abbaton, kol. 5-6; Adamo e Eva, kol. 73-76; Alessandrini, Lettera agli, kol. 196; Anania, apocrifo, kol. 268; Andrea Apostolo, apocrifi, kol. 285-287; Apocrifi nelle lingue orientali, kol. 404-407; Apocalissi apocrife, kol. 391-393; Apocrifi del AT cristiani e cristianizzati, kol. 403-404; Apostoli, kol. 435-441; Aquila, Atti di, kol. 453; Ascensione di Isaia, apocrifo, 570-571; Barnaba Apostolo, kol. 709-710; Bartolomeo, patristica e gli apocrifi, kol. 719-720; Buon Ladrone, kol. 822; Canone Muratoriano, kol. 842-843; Caverna dei Tesori, kol. 790-791; Ciriaco di Al-Bahnasa (Ossirinco) kol. 1044; Cirillo di Gerusalemme, Pseudo, kol. 1052; Dialoghi di Gesù, apocrifi, kol. 139-140; Dionigi Ps. Areopagita, apocrifi, kol. 1442-1443; Discesa agli inferi, apocrifo, kol. 1524-1525; Domenica lettera sulla, apocrifo, 1478-1479; Elenchi antichi di libri canonici ed apocrifi, kol. 1622-1624; Epifanio Monaco, kol. 1673; Epistula Apostolorum, kol. 1706; Esdra, apocrifi, kol. 1749; Eutimiaca storia, leggenda greca, kol. 1873; Evodio Ps. homelia, kol. 1890; Filippo apostolo (apocrifi), kol. 1951-1952; Galbios e Candidos, kol. 2031; Giacomo il Maggiore (apocrifo), kol. 2148; Giacomo il Minore (apocrifo), kol. 2150-2152; Giacomo (Minore). Protovangelo di, kol. 2150-2152; Giovanni evangelista teologo, kol. 2179-2182; Giovanni Battista, kol. 2187-2188; Giuda Iscariota (apocrifo), kol. 2271-2273; Giuda Taddeo (apocrifo), kol. 2276; Giuseppe di Arimatea (apocrifo), kol. 2392; Giuseppe Falegname. Storia di, kol. $2332-$ 2333; Guarigione di Tiberio, kol. 2481; Laodicesi Epistola, kol. 2736-2737; Lentulo (cd. Lettera di); kol. 2767; Libro dell'infanzia (latino), kol. 2835; Longino (figure negli apocrifi); kol. 2904; Mar Mari. Atti di, kol. 3005; Maria (letteratura patristica), kol. 3050-3055; Maria Magdalena, kol. 30563057; Matteo evangelista, kol. 3156-3158; Mattia apostolo (apocrifi); kol. 3161; Miracoli di Gesu, kol. 3297; Natività (apocrifi della), kol. 34263427; Natività di Maria (apocrifi), kol. 3427-3428;

Letteratura patristica, dir. A. di Berardino - G. Fedalto - M. Simonetti, Cinisello Balsamo (Milano) 2007, 111-118 (Apocrifa, letteratura).

\section{PRZEKEADY ${ }^{1}$}

Godne Pamięci sentencje Ojców (Apophthegmata Patrum) w: Błogosławiony Maksymilian wśród nas, red. B. Bejze, W nurcie zagadnień posoborowych 6, Warszawa 1972, 388-404.

${ }^{1}$ W niniejszym wykazie figurują tylko przekłady publikowane poza książkami i opracowaniami, przygotowanym przez ks. prof. Marka Starowieyskiego, wiele innych znajduje się zwłaszcza w seriach wydawniczych redagowanych przez Jubilata, a wskazanych w III rozdziale niniejszego wykazu (Wstępy, komentarze, wybór tekstów, oprac. redakcyjne i merytoryczne). 
O czym nie wspomina Ewangelia (wybór apokryfów), TP 26 (1972) nr 52-53, s. 4.

Odejście błogosławionej Dziewicy (apokryf) TP 26 (1972) nr 34, s. 1-2.

Silone I., Spotkanie z dziwnym księdzem, TP 26 (1972) nr 6, s. 1. 4-5 (jako Marek Rucz)

Zwiastowanie (wybór apokryfów), TP 27 (1973) nr 12, s. 1-2.

Agrafa (wybór), TP 29 (1975) nr 38, s. 4.

Hezychiusz Jerozolimski, Homilia na święty dzień Wielkiejnocy, TP 29 (1975) nr 13, s. 1.

Jan Moschos, Łaka duchowa (fragm.), „Znak” 27 (1975) nr 6, 799-810.

Narodziny Maryi (apokryf), TP 29 (1975) nr 50, 4.

Ramki patrystyczne, TP 29 (1975): Cyryl Jerozolimski, nr 20, s. 1; św. Augustyn, nr 21, s. 1 ; nr 43, s. 1 ; nr 45, s. 2; nr 50, s. 2; św. Justyn, nr 22, s. 1; św. Leon Wielki, nr 26, s. 3; nr 37, s. 2; św. Jan Chryzostom, nr 27, s. 3; nr 28, s. 3; nr 29, s. 3 ; nr 30, s. 2 ; nr 31, s. 2 ; nr 35, s. 2; nr 36, s. 2; Orygenes, nr 32, s. 2; nr 49, s. 2; św. Beda, nr 33, s. 2; nr 48, s. 2; Innocenty III, nr 34, s. 2; Balaj, nr 39, s. 3; św. Ambroży, nr 40, s. 2; św. Hieronim, nr 41, s. 2; św. Grzegorz Palamas, nr 44, s. 2; św. Grzegorz z Nazjanzu, nr 4, s. 27.

Chrzest Chrystusa (z apokryfów) TP 30 (1976) nr 2, s. 1.

Ewangelia Piotra, TP 30 (1976) nr 15, s. 2.

Khalil Gibran, Prorok (fragm.), TP 30 (1976) nr 10, s. 5.

Marcin z Brakary, Sentencje Ojców Egipskich, „Znak” 28 (1976) nr 11, 14921507.

Neofita Rekluz, Wniebowzięcie, TP 30 (1976) nr 33, s. 1.

Opowiadanie Józefa z Arymatei, RBL 29 (1976) 27-34.

Ramki patrystyczne, TP 30 (1976): św. Leon Wielki, nr 1, s. 2; nr 11, s. 2, nr 38, s. 2; św. Augustyn, nr 3, s. 2; nr 12, s. 2; nr 14, s. 2; nr 20, s. 2; nr 34, s. 2; nr 44, s. $2 ; n$ r 47, s. 2; św. Beda, nr 4, s. 2; nr 8, s. 2; nr 28, s. 2; nr 29, s. 2; nr 35, s. 2; św. Hieronim, nr 6, s. 2; nr 10, s. 2; św. Jan Chryzostom nr 7, s. 2; nr 27, s. 2; nr 37, s. 2; nr 40, s. 2; Liturgia wizygocka, nr 13, s. 2; św. Grzegorz Wielki, nr 17 , s. 2 ; nr 21, s. 2 ; nr 43, s. 2 ; nr 48, s. 2 ; nr 49, s. 2; nr 50, s. 2; bł. Guerric, nr 18, s. 2; św. Tomasz z Akwinu, nr 19, s. 2; Do Diogneta, nr 22, s. 2; św. Cyryl Jerozolimski, nr 23, s. 1; nr 46, s. 2; św. Jan Damasceński, nr 24, s. 24; Dionizy Ps. Areopagita, nr 25, s. 2; św. Efrem, nr 26, s. 2; nr 30, s. 2; Firmicus Maternus, nr 32, s. 2; Baldwin z Ford, nr 32, s. 2; św. Grzegorz z Nazjanzu, nr 36, s. 2; Euzebiusz z Cezarei, nr 39, s. 2; Klemens Aleksandryjski, nr 41, s. 2; Teodor z Mopsuestii, nr 42, s. 2; Paulin z Noli, nr 45, s. 2; Orygenes, nr 51, s. 8.

Roman Pieśniarz, Hymn o Zmartwychwstaniu, TP 30 (1976) nr 16, s. 1.

U źródet (cykl tłumaczeń), ChS (1976): List do Diogneta, nr 39/1, s. 3-6; Tertulian, nr 40/2, s. 38-41; Didache, nr 41/3, s. 57-60; Św. Justyn i Teofil Antiocheński, nr 48/10, s. 67-68. 
Ewangelie Apokryficzne (wybór), „Znak” 29 (1977) nr 5, 535-567.

Kawaler d'Arvieu, Odwiedziny u Patriarchy Maronitów, TP 31 (1977) nr 37, s. 2.

Ramki patrystyczne, TP 31 (1977): św. Grzegorz z Nazjanzu, nr 2, s. 2; św. Augustyn, nr 3, s. 2 ; nr 13, s. 2; nr 16, s. 2; nr 17, s. 2; nr 18, s. 2; nr 19, s. 2 ; nr 20, s. 2; nr 22, s. 2; nr 24, s. 2; nr 41, s. 2; nr 42, s. 2; Orygenes, nr 4, s. 2; nr 5, s. 2; nr 23, s. 2; św. Ambroży, nr 6, s. 2; nr 29, s. 2; nr 46, s. 2; św. Beda, nr 7, s. 2; nr 8, s. 2; św. Leon Wielki, nr 9, s. 2; nr 10, s. 2; Tertulian, nr 11, s. 2; Nerses Sznorhali, nr 12, s. 2; św. Efrem, nr 14, s. 2; nr 27, s. 2; nr 51-52, s. 2; św. Ignacy Antiocheński, nr 21, s. 2; św. Grzegorz Wielki, nr 25, s. 2; nr 50, s. 2; Filoksen z Mabbug, nr 26, s. 2; Klemens Aleksandryjski, nr 28, s. 2; nr 37, s. 2; Teodor z Mopsuestii, nr 30, s. 2; Bazyli, nr 31, s. 2; nr 43, s. 2; św. Bazyli Wielki, nr 32, s. 2; św. Jan Chryzostom, nr 33, s. 2; nr 39, s. 2; św. Hieronim, nr 34, s. 2; nr 35, s. 2; tzw. II List Klemensa, nr 38, s. 2; Jan Kasjan, nr 40, s. 2; Cyryllonas, nr 44, s. 2; św. Justyn, nr 45, s. 2; św. Roman Pieśniarz, nr 47, s. 2; bł. Guerric z Igny, nr 48, s. 2; św. Hilary z Poitiers, nr 49, s. 2.

Mondésert C., Wnioski z konferencji o męczennikach Lyońskich, STV 16 (1978) nr 2, 253-258.

Ramki patrystyczne, TP 32 (1978): św. Jan Chryzostom, nr 1, s. 2; nr 4, s. 2; nr 6, s. 2; św. Chromacjusz z Akwilei, nr 2, s. 2; nr 11, s. 2; św. Ireneusz, nr 3, s. 2; Nerses Sznorhali, nr 5, s. 2; św. Grzegorz Wielki, nr 7, s. 2; św. Atanazy Synaita, nr 8, s. 2; św. Jan Damasceński, nr 9, s. 2; Anonim IX w., nr 10, s. 2; nr 12, s. 2; bł. Guerric z Igny, nr 49, s. 1-2.; Jakub z Sarug, nr 50, s. 1. Roman Pieśniarz, Hymn na Boże Narodzenie, TP 32 (1978) nr 52-53, s. 3. Nerses Šnorhali, Wielkopostna modlitwa powszechna, TP 33 (1979) nr 9, s. 2. Ramki patrystyczne, TP 33 (1979): św. Augustyn, nr 12, s. 2; św. Amadeusz z Lozanny, nr 33, s. 2.

List Apostolski „Patres Ecclesiae”, OsRomPol (1980) nr 3, s. 14-16.

List Apostolski „Sanctorum Altrix”, OsRomPol (1980) nr 12, s. 11-13 [= Mod-

litwa i praca, red. B. Bejze, W nurcie zagadnień posoborowych 13, Warszawa 1981, 16-34].

Na święte Triduum Paschalne (wybór tekstów), TP 34 (1980) nr 13, s. 1.

Reguła św. Augustyna, „W drodze” 8 (1980) nr 7, 12-27.

Verbraken P.P, Panorama patrystyczna (cykl), GN 58 (1981); Ojcowie Kościota 58 (1981) nr 30, s. 1, 4-5; Klemens Rzymski, 58 (1981) nr 35, s. 4; Ignacy, Biskup Antiochii, 58 (1981) nr 42, s. 4; Didache, 59 (1982) nr 3, s. 3.

Ojcze nasz Ojców Kościoła (cykl) „W drodze” 11 (1983) nr 11, s. 106-107; nr 12, s. $102-107$.

Ortiz de Urbina I., Maryja w patrologii syryjskiej, przekład wraz z K. Niklewicz, „Częstochowskie Studia Teologiczne” 11 (1983) 95-171.

Ujrzeli, tłum. M. Starowieyski, ,Tygodnik Polski” 2 (1983) nr 13/14, s. 1 
„Apokalipsa Piotra”, przekład tekstu greckiego, wstęp, komentarz i oprac., WST 2 (1984) 48-78.

Marcin z Bragi. Teksty prawne, wstęp, oprac., częściowo przekład, WST 2 (1984) $79-121$.

Ojcze nasz Ojców Kościoła, (cd. cyklu z roku 1983), „W drodze” 12 (1984) nr 2, 104-107; nr 3, 102-107; nr 4, 101-107; nr 9, 104-107; nr 10, 105-107.

Verbraken P.P., Panorama patrystyczna (cykl), PKat 72 (1984) nr 5 (Panorama patrystyczna); 72 (1984) nr 9, s. 2 (Didache); 72 (1984) nr 11, s. 2 (św. Ignacy Antiocheński); 72 (1984) nr 13, s. 2 (List do Diogneta).

Św. Tomasz z Akwinu, Wykład Modlitwy Pańskiej, w: Św. Tomasz z Akwinu, Wykład pacierza, Poznań 1987², 63-90.

Św. Efrem, Zwiastowanie, „W drodze” 16 (1988) nr 7, 105-107.

Męka Pańska według Diatessaronu, RBL 42 (1989) nr 4, 259-267.

Czternaście homilii z IX wieku, tłum. M. Starowieyski - S. Grabowski, WST 3 (1985-1990) 206-223.

Grzegorz z Nareku, Stowo 77, w: Grzegorz z Nareku, Księga śpiewów żałobliwych, Warszawa 1990, 389-392.

Dzieje Pawła i Tekli (przekład), RBL 44 (1991) nr 4-6, 118-126.

Jan Chryzostom, Nie żadam od ciebie zapłaty, „W drodze” 20 (1992) nr 8, 108. Przekłady tekstów eucharystycznych (Izaak Wielki, Narsai, św. Efrem, Serapion $z$ Thmuis), „W drodze” 21 (1993) nr 6, s. 4. 12. 60. 69. 72. 106-107.

Malingrey A.M., Chrześcijańska literatura grecka, przekład i oprac. M. Starowieyski, Tarnów 1995.

Regnault L., Ojcowie pustyni, tłum. M. Starowieyski, „List” 8 (1995) nr 3, 15-16.

Tharaud J. i H., Ostatnia z odwiedzających, tłum. M. Starowieyski, „Jasna Góra" 15 (1997) nr 12, 18 (= GN 1996, nr 51/52, s. 7).

Św. Tomasz z Akwinu, Wykład Modlitwy Pańskiej czyli Ojcze nasz, w: Św. Tomasz z Akwinu, Dzieła wybrane, oprac. i wstępami poprzedził J. Salij, Kęty 1999, 618-641.

Św. Augustyn, Ordo monasterii. Praeceptum, w: Św. Augustyn, Pisma monastyczne, tłum. M. Starowieyski, ŹM 27, Kraków 2002, 155-168.

Św. Tomasz z Akwinu: Wykład Modlitwy Pańskiej czyli „Ojcze nasz”, w: Św. Tomasz z Akwinu, Wykład pacierza, Poznań 2005, 79-116.

\section{ZBIORY BIBLIOGRAFII}

Bibliografia mariologii patrystycznej wschodniej, „Częstochowskie Studia Teologiczne" 6 (1978) 94-104.

Bibliografia Egeriana, „Augustinianum” 19 (1979) 279-318.

Bibliografia mariologii patrystycznej zachodniej, „Częstochowskie Studia Teologiczne" 7 (1979) 175-187. 
Bibliografia (literatury chrześcijańskiej tacińskiej) w: J. Fontaine, Chrześcijańska literatura tacińska. Rys historyczny, tłum. J. Słomka, Tarnów 1997, 203-242.

\section{RECENZJE, SPRAWOZDANIA, OMÓWIENIA}

Biuletyn patrystyczny, CT 48 (1978) nr 3: A. Paredi o św. Ambrożym, s. 177178; Nowa seria studiów patrologicznych - Studia patristica Mediolanensia, s. $178-180$.

Konferencja o męczennikach lyońskich 177 roku, STV 16 (1978) nr 2, 249252.

Biuletyn patrystyczny, CT 49 (1979) nr 3: Wokót „Słowa prawdziwego” Kelsosa, s. 183-184; Ojcowie Kościoła w duszpasterstwie, s. 184-187; Chrysostomica, s. 187-188; Wydanie kateny Synaickiej, s. 188-189.

Biuletyn patrystyczny, CT 49 (1979) nr 4: Opera minora M. Richarda, s. 186189; Dzieto naukowe ks. F. Halkin, bollandysty, s. 189-191.

Biuletyn patrystyczny, CT 50 (1980) nr 1: Z historii badań nad antykiem chrześcijańskim, s. 168-169; Popularyzacja Ojców Kościoła, s. 169-170; Polskie ttumaczenie apokryfów, s. 170; Publikacje o tematyce patrystycznej Studium Biblijnego Franciszkanów w Jerozolimie, s. 171-174; "Apophthegmata”, s. 174-176; Nowy Numer „Jahrbuch für Antike und Christentum", s. 168-176.

Biuletyn patrystyczny, CT 50 (1980) nr 4: Przeglad czasopisma „Classical Folia", s. 155-159; Zmarli, s. 163.

Biuletyn patrystyczny, CT 51 (1981) nr 1: Publikacje opactwa Bellefontaine dotyczace duchowości wschodniej, s. 139-141; Przekłady apoftegmatów, s. 141-142.; VIII Międzynarodowa Konferencja Studiów Patrystycznych (Oxford, 3-6 IX 1979), s. 144-146; Kolokwium bazyliańskie w Chevetogne, s. 147.

Biuletyn patrystyczny, CT 51 (1981) nr 2: Encyklopedia augustiańska, s. 157159; Przegląd czasopisma „Analecta Bollandiana” 97 (1979), s. 159; Przegląd czasopisma „Jahrbuch für Antike und Christentum” 22 (1979), s. 160 .

Biuletyn patrystyczny, CT 51 (1981) nr 4: Starożytność chrześcijańska w „Theologische Realenzyklopädie”, s. 165-167.

Biuletyn patrystyczny, CT 52 (1982) nr 1: Nowe tomy "Corpus Christianorum”, series Graeca, s. 171-176; „Chrześcijańskie tomy” serii „Aufstieg und Niedergang der römischen Welt”, s. 176-177; ,Jahrbuch für Antike und Christentum 23 (1980), s. 178; Wśród jugostowiańskich publikacji patrystycznych, s. 178-179; Przekład starożytnych regut zakonnych, s. 179-180; Czy Orygenes zostat potępiony?, s. 181-183; Zmarli, s. 185-186. 
Biuletyn patrystyczny, CT 52 (1982) nr 2: Wyznanie nicejsko-konstantynopolitańskie wyznaniem wiary całego chrześcijaństwa, s. 173-175.

Hamman A., Życie codzienne pierwszych chrześcijan, Warszawa 1990 i tenże, Życie codzienne w Afryce pótnocnej w czasach św. Augustyna, Warszawa 1989; rec. w: „Studia Franciszkańskie” 5 (1992) 368-371.

Kronika apokryfów, WST 5 (1992) 219-223.

Dwie ksiązki o modlitwie wczesnochrześcijańskiej, ,W drodze” 21 (1993) nr 12, 90-94.

Kronika apokryfów Nowego Testamentu I, WST 6 (1993) 307-310.

Kronika patrystyczna (1), WST 6 (1993) 299-306.

Informacje o ksiażkach, recenzje (prace o Paulinie z Noli, Augustinus-Lexicon, Eustratii Presbyteri „Vita Eutychii”; Sant'Agostino, Confessioni), Kronika apokryfów, „Meander” 5-6 (1994) 303-312.

Kronika patrystyczna (2), WST 7 (1994) 259-262.

Kronika apokryfów (3), WST 7 (1994) 263-267.

Kronika patrystyczna (3), WST 7 (1994) 321-328.

Dwa tomy „Corpus Christianorum”, WST 8 (1995) 273-275.

Elementy patrystyczne w aktach Sympozjów w Efezie i w Tarsie, WST 8 (1995) 271-273.

Zemsta stereotypu czyli Ewy Wipszyckiej Kościót w świecie późnego antyku, „W drodze” 23 (1995) nr 9, 90-94.

Kronika apokryfów (4), WST 11 (1998) 329-341.

Corpus Nazianzenum w serii Corpus Christianorum, Series Graeca, WST 14 (2001) 219-222.

Nowe tomy Corpus Christianorum, Series Graeca dotyczace Maksyma Wyznawcy, WST 14 (2001) 222-223.

Zowczak M., Biblia ludowa, Warszawa 2000; rec. „Apocrypha” 14 (2003) 311 313.

Studia z dziedziny historii literatury wczesnochrześcijańskiej i patrologii w Polsce. Próba oceny sytuacji, „Meander” 58 (2003) 163-170.

Aegyptus Christiana. Mélanges d'hagiographie égyptienne et orientale dédiés à la mémoire du P. Paul Devos, Bollandiste, cur. U. Zanetti - E. Lucchesi, Genève 2004; rec. VoxP 24 (2004) t. 46-47, 655-658.

Dokumenty Soborów Powszechnych. Tekst łaciński, arabski, ormiański, polski, t. 3: (1414-1445). Konstancja. Bazylea - Ferrara - Florencja - Rzym, układ i oprac. A. Baron - H. Pietras, Kraków 2003; rec. „Nasza Przeszłość” (2004) nr 101, 479-482.

Flis A. - Kowalska B., Zapomniani bracia. Ginący świat chrześcijan Bliskiego Wschodu, Kraków 2003; rec. „Przegląd Piśmiennictwa Teologicznego” 10 (2004) 19-20. 


\section{ARTYKUモY POPULARNONAUKOWE I PUBLICYSTYKA}

W oczach księdza, TP 18 (1964) nr 29, s. 1, 5 (jako Marek Rucz). Prymicje, TP 19 (1965) nr 25, s. 3 (jako Marek Rucz).

Ludzie z barokowego kościoła, TP 20 (1966) nr 35, s. 1 (jako Marek Rucz). Ciocia Zosia. Wspomnienie o Zofii Starowieyskiej-Morstinowej, TP 21 (1967) nr 27, s. 3, (jako Marek Rucz) [= Ciocia Zosia .., w: Z. Starowieyska-

Morstinowa, Ci, których spotykałam, Warszawa 1993, s. 21-30].

O „,babciach” bez ironii, TP 21 (1967) nr 52/53, s. 4 (jako Marek Rucz).

Dom zawiedzionych nadziei, PK 59 (1969) nr 6, s. $54-55$ (jako Marek Rucz). Najświętszej Maryi Panny odnaleziony?, TP 27 (1973) nr 33, s. 7

Pisarze ciagle aktualni, TP 28 (1974) nr 16, s. 6.

Testimonium Flavianum, TP 28 (1974) nr 6, s. 5.

Znasz-li ten kraj, gdzie cytryna dojrzewa, TP 28 (1974) nr 32, s. 6 (jako Marek Rucz).

Św. Pawet i 7 owiec, TP 29 (1975) nr 19, s. 8.

Jeszcze raz o „Trylogii” prof. Krawczuka, TP 29 (1975) nr 23, s. 4-5.

Luigi Orione - rzecz o dziwnym księdzu, TP 29 (1975) nr 51-52, s. 6-7.

„Trylogia” prof. Aleksandra Krawczuka, TP 29 (1975) nr 15, s. 3

Wędrówki pani Egerii, „Znak” 27 (1975) nr 6, s. 688-700.

W Jerozolimie, w końcu IV wieku, TP 29 (1975) nr 12, s. 5.

Ztoto scytyjskie, TP 30 (1976) nr 38, s. 5.

Eucharystia pierwszych chrześcijan, TP 31 (1977) nr 24, s. 1 i 7.

Korespondencja Chrystusa z Abgarem, królem Edessy, TP 31 (1977) nr 18, s. 6. Maronici, TP 31 (1977) nr 37, s. 4.

Ojcowie, których można czytać, TP 31 (1977) nr 3, s. 5.

Lugduni, A. D. 177, TP 31 (1977) nr 50, s. 5.

Nad świętym Augustynem, TP 32 (1978) nr 2, s. 3.

Ostatnia audiencja Jana Pawła I, PK 68 (1978) nr 46, s. 4 i 6.

Św. Ambroży, czyli umiłowanie Pisma św., TP 32 (1978) nr 20, s. 4.

Wokót Justyniana i Teodory, TP 32 (1978) nr 15, s. 3.

Kelsos, Orygenes iśw. Augustyn, TP 33 (1979) nr 16, s. 4.

Mój mały światek, PrzKat 69 (1979) nr 1, s. 3.

Ojcowie naprawdę żywi, TP 33 (1979) nr 33, s. 6

Św. Bazyli Wielki - w 1600 rocznice śmierci, PrzKat 69 (1979) nr 38, s. 4-6.

Watykan przez dziurke od klucza, TP 33 (1979) nr 8, s. 4.

Patres Ecclesiae. List apostolski Ojca św. Jana Pawła II na 600-lecie śmierci św.

Bazylego, TP 34 (1980) nr 12, s. 5.

Wędrówki benedyktyńskie, TP 34 (1980) nr 19, s. 1-2.

Dlaczego Kościót starożytny?, PK 75 (1987) nr 4, s. 1-2.

Nad „Ostatnia pokusą, PK 76 (1988) nr 49, s. 3 i 7.

Habemus missale, PK 77 (1989) nr 36, s. 2-3. 
Notatki z sejmiku nawiedzonych, w: Sacrum i sztuka, oprac. N. Cieślińska, Kraków 1989, 232-237.

Ostatnia Pokusa, PK 77 (1989) nr 2, s. 5.

Barwne średniowiecze, PK 77 (1989) nr 6, s. 6.

Brzydkie kaczątko rodziny Frassatich, TP 42 (1989) nr 51, s. 4.

Formacja kulturowa przyszłych kapłanów, AK 81 (1989) t. 112, 392-406.

Zychiewiczowe obstukiwanie człowieka, TP 42 (1989) nr 52-53, s. 8.

Dlaczego Kościót starożytny?, w: Chrześcijaństwo wśród religii, red. M. Wojciechowski, Warszawa 1990, 151-156.

Tadeuszowi Żychiewiczowi w odpowiedzi, PK 78 (1990) nr 2, s. 1 i 7.

Życie w gminie chrześcijańskiej na przełomie I i II wieku, PK 80 (1990) nr 22,

s. 6.

Epopeja misyjna, „Niedziela” 34 (1991) nr 42, s. 2.

Seminaria i co dalej?, „W drodze” 19 (1991) nr 6, s. 90-94.

Czy naprawdę Ojcowie pustyni?, „Niedziela” 35 (1992) nr 17, s. 5.

Jakub Większy, Apostot, „W drodze” 20 (1992) nr 8, 368-77.

Jeszcze raz o Watykanie, ,Niedziela” 35 (1992) nr 11, s. 6.

Ludzie są dobrzy, „Aspekty” 8 (1992) nr 10, s. 16.

Sobory niepodzielonego Kościoła; cykl w: „Niedziela”: 1. Kościót przedsoborowy, 35 (1992) nr 22, s. 3; 2. Sobór Nicejski I (325), 35 (1992) nr 25, s. 2; 3. Sobór Konstantynopolitański I (381), 35 (1992) nr 27, s. 2; 4. Sobór Efeski (431), 35 (1992) nr 29, s. 2; 5. Sobór Chalcedoński (451), 35 (1992) nr 31, s. 2; 6. Sobór Konstantynopolitański II (553), 35 (1992) nr 34, s. 2; 7. Sobór Konstantynopolitański III (680/681), 35 (1992) nr 39, s. 2; 8. Sobór Nicejski II (787), 35 (1992) nr 45, s. 2.

W domu niewoli, „Niedziela” 35 (1992) nr 3, s. 6.

Zapiski z włóczęgi, 1-2, GN 69 (1992) nr 39, s. 9; 69 (1992) nr 40, s. 9.

Życie nienarodzonych w starożytności chrześcijańskiej, „Aspekty” 8 (1992) nr 9, s. 16.

Życie nienarodzonych w starożytności niechrześcijańskiej, „Aspekty” 8 (1992) nr 7-8, s. 14.

Ciocia Zosia, w: Z. Starowieyska-Morstinowa, Ci, których spotykałam, Warszawa 1993, s. 21-30.

Eucharystia pierwszych chrześcijan, PK 81 (1993) nr 18, 4-5. (= „Powściągliwość i Praca” 12:1995, s. 9 = „Pielgrzym” 6:1995, nr 13, s. 5)

Hipokrates ocenzurowany, GN 70 (1993) nr 13, s. 6.

Księża-poeci czy poezja kapłańska?, „W drodze” 21 (1993) nr 5, 102-103.

Mądry świat don Camilla, „W drodze” 21 (1993) nr 11, 104-105.

Mowa liczb, „Aspekty” 9 (1993) nr 5, s. 31.

Notatki z włóczęgi, GN 70 (1993) nr 38, s 17.

Notatki z włóczęgi. Głód w Bieszczadach, GN 70 (1993) nr 37, s. 17.

Notatki z włóczęgi. Pielgrzymki, GN 70 (1993) nr 36, s. 20. 
Paweł biskup Monembasii, O Sergiuszu, obywatelu Aleksandrii, „List” 10 (1993) nr 10, 24-25.

Poczatki kultu świętych, PK 81 (1993) nr 22, s. 4.

Pokuta pierwszych chrześcijan, PK 81 (1993) nr 7, s. 6.

Stużba liturgiczna we wspótczesnym Kościele, ,Msza Święta” 49 (1993) nr 2, s. 49.

U grobu św. Ryty [Sanktuaria - dar Boga], GN 70 (1993) nr 30, s. 7.

Wołanie o jedność, PK 81 (1993) nr 1, s. 8.

Założyciel Tyńca, „Aspekty” 9 (1993) nr 4, s. 33.

Człowiek odwagi apostolskiej i heroicznej nadziei (wspomnienie o kardynale

Gabrielu-Marii Garrone) „Słowo” 2 (1994) nr 10 (21).

Mariologia Ojców Kościoła 1 (św. Ignacy Antiocheński), „Jasna Góra” 12 (1994) $\mathrm{nr} 1,22$.

Mariologia Ojców Kościoła 2 (św. Justyn), „Jasna Góra” 12 (1994) nr 2, 18.

Mariologia Ojców Kościoła 3 (Protoewangelia Jakuba 1), „Jasna Góra” 12 (1994) $\mathrm{nr} 3,25-26$.

Mariologia Ojców Kościoła 4 (Protoewangelia Jakuba 2), „Jasna Góra” 12 (1994) $\mathrm{nr} \mathrm{4,} \mathrm{14-15.}$

Mariologia Ojców Kościoła 5 (Ody Salomona), „Jasna Góra” 12 (1994) nr 6, 19. Mariologia Ojców Kościoła 6 (Ireneusz z Lyonu), „Jasna Góra” 12 (1994) nr 9 , 15-16.

Mariologia Ojców Kościoła. Orygenes (1), „Jasna Góra” 12 (1994) nr 12, 2-3. Rzecz o dynamicznym jezuicie [Maksymilian Ryłło], ,W drodze” 22 (1994) nr 1, 98-101.

Wakacyjne wędrówki: Oczyma mola książowego, GN 71 (1994) nr 36, s. 8.

Wakacyjne wędrówki: W Burgundii i w Jurze, GN 71 (1994) nr 38, s. 9.

Wakacyjne wędrówki: Wędrówki po Kościele, GN 71 (1994) nr 37, s. 21.

Wieża Babel czy pluralizm?, ,Słowo”, 2 (1994) nr 15 (26), s. 22.

Apologeci, „Pielgrzym” 6 (1995) nr 14, s. 5.

Duch niespokojny - Tertulian, „Pielgrzym” 6 (1995) nr 16, s. 5 [= „Powściągliwość i Praca” 47:1996, nr 3, s. 8].

Dzieło genialnego teologa, „Pielgrzym” 6 (1995) nr 19, s. 5.

Eucharystia pierwszych chrześcijan, „Pielgrzym” 6 (1995) nr 13, s. 5 [= „Powściągliwość i Praca” 46:1995, nr 12, s. 9].

Humanista chrześcijański, „Pielgrzym” 6 (1995) nr 18, s. 5 [= „Powściągliwość i Praca" 47: 1996, nr 5, s. 11].

Interwencja biskupa Rzymu, ,Pielgrzym” 6 (1995) nr 5, s. 5 [= „Powściągliwość i Praca" 46:1995, nr 3, s. 24].

Mariologia Ojców Kościoła. Orygenes (2), „Jasna Góra” 13 (1995) nr 1, s. 21. Mariologia Ojców Kościoła. Orygenes (3), „Jasna Góra” 13 (1995) nr 2, s. 19. Mariologia Ojców Kościoła. Orygenes (4), „Jasna Góra” 13 (1995) nr 3, s. 18. Mariologia Ojców Kościoła. Tertulian (1), ,Jasna Góra” 13 (1995) nr 7-8, s. 44. Mariologia Ojców Kościoła. Tertulian (2), „Jasna Góra” 13 (1995) nr 9, s. 22. 
Miejsce Chrystusa $w$ dziejach świata, „Pielgrzym” 6 (1995) nr 7, s. 5 [= „Powściągliwość i Praca" 46:1995, nr 9, s. 10].

Mój przyjaciel don Camillo; cykl w: GN 72 (1995): 1. Spotkanie z don Camillo, tamże, nr 9, s. 12; 2. Siła dobroci, tamże, nr 11; 3. Drętwa mowa, tamże, nr 22, s. 14; 4. Don Camillo mistyk, tamże, nr 29, s. 23; 5. Trudna sztuka kompromisu, tamże, nr 36; 6. Smiech tak bardzo potrzebny, tamże, $\mathrm{nr} 42$, s. 22.

Ojciec historii Kościoła, „Pielgrzym” 6 (1995) nr 24, s. 5.

O zadaniach chrześcijan $w$ świecie, „Pielgrzym” 6 (1995) nr 12, s. 5 [= „Powściągliwość i Praca" 46:1995, nr 11, s. 8].

Początki kultu świętych, „Pielgrzym” 6 (1995) nr 9, s. 5 [= „Powściągliwość i Praca" 46: 1995, nr 6, 27-28].

Początki problematyki pokutnej, „Pielgrzym” 6 (1995) nr 10, s. 7 [= „Powściągliwość i Praca" 46:1995, nr 7-8, s. 32].

Św. Cyprian - umiłowanie Kościoła, „Pielgrzym” 6 (1995) nr 17, s. 5 [= „Powściągliwość i Praca” 47:1996, nr 4, s. 10].

Św. Justyn męczennik - czlowiek dialogu, „Pielgrzym” 6 (1995) nr 15, s. 5. Wielki Atanazy, „Pielgrzym” 6 (1995) nr 27, s. 5.

Wołanie o jedność - Ignacy Antiocheński, „Pielgrzym” 6 (1995) nr 6, s. 5. Życie w gminie chrześcijańskiej na przełomie I i II wieku, „Pielgrzym” 6 (1995) nr 4, s. 3 [= „Powściągliwość i Praca” 46:1995, nr 2, s. 14]. Ambroży, „Pielgrzym” 7 (1996) nr 18, s. 5. Apologeci, „Powściągliwość i Praca” 47 (1996) nr 1, s. 28. Apostołowie; cykl w: „Niedziela” 39 (1996): Apostołowie (1), 39 (1996) nr 29, s. 14; Apostołowie (2), 39 (1996) nr 31, s. 9; Św. Piotr (1), 39 (1996) nr 33, s. 15; Św. Piotr (2), 39 (1996) nr 35, s. 11; Św. Andrzej, 39 (1996) nr 37, s. 10; Św. Jakub Większy, Zebedeuszowy, 39 (1996) nr 39, s. 11; Św. Jan (1), 39 (1996) nr 41, s . 8; Św. Jan (2), 39 (1996) nr 44, s. 13; Św. Filip, 39 (1996) nr 47, s. 12; Św. Barttomiej, 39 (1996) nr 50, s. 18.

Aureliusz Augustyn (1), „Pielgrzym” 7 (1996) nr 20, s. 5. Aureliusz Augustyn (2), „Pielgrzym” 7 (1996) nr 21, s. 5. Biskup Hilary, „Pielgrzym” 7 (1996) nr 16, s. 5. Bracia Jezusa (św. Hilary z Poitiers), „Jasna Góra” 14 (1996) nr 3, s. 18. Burzliwe dzieje humanisty, „Pielgrzym” 7 (1996) nr 15, s. 5. Informator niefortunny, „Słowo. Dziennik Katolicki” (,Słowo” Warszawskie) 4 (1996) nr 57, s. 3.

Kontrowersyjny patriarcha, „Pielgrzym” 7 (1996) nr 14, s. 5. Ksiąze egzegetów - święty Hieronim, „Pielgrzym” 7 (1996) nr 19, s. 5. Maria prorokini, (Afrahat), „Jasna Góra” 14 (1996) nr 1, s. 16. Niefortunne: odpowiedź, teologia, robota, „Słowo. Dziennik Katolicki” 4 (1996) nr 71, s. 5.

Niestrudzona wędrowniczka, „Pielgrzym” 7 (1996) nr 7, s. 5. 
Ojciec mistyki chrześcijańskiej, „Pielgrzym” 7 (1996) nr 3, s. 5.

Otwarci na zło. Na marginesie ankiety „Więzi”, „Słowo. Dziennik Katolicki” 4 (1996) $\mathrm{nr} 88$, s. 5.

Orygenes - genialny teolog, „Powściągliwość i Praca” 47 (1996) nr 6, s. 12.

Piekielne pytania, „Słowo. Dziennik Katolicki” 4 (1996) nr 208, s. 4.

Pierwszy wielki poeta chrześcijański, „Pielgrzym” 7 (1996) nr 2, s. 5.

Platonik w mitrze, „Pielgrzym” 7 (1996) nr 13, s. 5.

Pokuta serca i ciała, „Słowo. Dziennik Katolicki” 4 (1996) nr 63, s. $5 .$.

Świat pisarzy syryjskich, „Pielgrzym” 7 (1996) nr 10, s. 5.

Św. Justyn męczennik, człowiek dialogu, „Powściągliwość i Praca” 47 (1996)

nr 2, s. 12.

Wielcy poeci chrześcijańscy, „Pielgrzym” 7 (1996) nr 22, s. 5.

Wielki katecheta, „Pielgrzym” 7 (1996) nr 8, s. 5.

Wielki organizator Kościoła, „Pielgrzym” 7 (1996) nr 1, s. 5.

Wielki papież epoki najazdów barbarzyńców, „Pielgrzym” 7 (1996) nr 24, s. 5.

W kręu Lerynu, „Pielgrzym” 7 (1996) nr 23, s. 5.

W środowisku antiocheńskim, „Pielgrzym” 7 (1996) nr 4, s. 5.

Wśród mnichów egipskich, „Pielgrzym” 7 (1996) nr 12, s. 7.

Złotousty, „Pielgrzym” 7 (1996) nr 5, s. 5.

Apostołowie, cykl w: „Niedziela” 40 (1997): Św. Tomasz, 40 (1997) nr 2, s. 11;

Św. Mateusz, 40 (1997) nr 4, s. 15; Św. Jakub Alfeuszowy, 40 (1997) nr 7, s. 12; Św. Juda Tadeusz, 40 (1997) nr 12, s. 12; Św. Szymon, 40 (1997) nr 16, s. 13; Judasz, 40 (1997) nr 19, s. 10; Św. Maciej, 40 (1997) nr 29, s. 15; Św. Pawet (1) 40 (1997) nr 35, s. 10; Św. Pawet (2) 40 (1997) nr 37, s. 12; Kult Apostołów, 40 (1997) nr 42, s. 8; Apostołowie jako zjawisko kulturowe, 40 (1997) $\mathrm{nr}$ 45, s. 14.

Bluźnierstwo, „Rzeczpospolita” 1997, nr 63, s. 17.

Grzegorz Wielki, „Pielgrzym” 8 (1997) nr 4, s. 5.

Dziwna i bogata ziemia, „Pielgrzym” 8 (1997) nr 15, s. 5.

Maksym Wyznawca, „Pielgrzym” 8 (1997) nr 12, s. 5.

Maryja dała światu mannę (Maksym z Turynu), „Jasna Góra” 15 (1997) nr 6, s. 10.

Maryja przybywa do Monopoli, „Pielgrzym” 8 (1997) nr 16, s. 5.

Mąż Boży, ,Agora” (1997) nr 8, s. 6-7.

Mąż Boży, ,Jasna Góra” 15 (1997) nr 6, s. 5-8.

Na dworze króla Teodoryka, „Pielgrzym” 8 (1997) nr 1, s. 5.

Na „obcasie” buta wtoskiego, „Pielgrzym” 8 (1997) nr 17, s. 5.

Ojcowie Pustyni; cykl w: „List” 14 (1997): Pod stońcem szatana, nr 3, s. 7-9; Kto stoi niech baczy, aby nie upadt, nr 4, s. 22-23.; Im blizej Boga tym blizej czlowieka, nr 5, s. 30-31.

Ostatni Ojciec Kościoła - Beda Wielebny, „Pielgrzym” 8 (1997) nr 7, s. 4.

Ostatni Ojciec Kościoła -św. Jan Damasceński, „Pielgrzym” 8 (1997) nr 13, s. 5. 
Oto Matka Twoja (św. Augustyn), ,Jasna Góra” 15 (1997) nr 3, s. 8. Piekielne kompromitacje, „Słowo. Dziennik Katolicki” 4 (1997) nr 8, s. 8. Piekielne rozmydlanie, „Niedziela” 40 (1997) nr 43, s. 8.

Retoryka czy homiletyka? Kazania Ojców Kościoła, „Pielgrzym” 8 (1997) nr 10, s. 5 .

Poezja bizantyńska, „Pielgrzym” 8 (1997) nr 11, s. 5.

Wielki encyklopedysta - Izydor z Sewilli, „Pielgrzym” 8 (1997) nr 5, s. 4.

W kręgu piewców św. Marcina, „Pielgrzym” 8 (1997) nr 3, s. 5.

W świecie mnichów wschodnich i zachodnich, „Pielgrzym” 8 (1997) nr 8, s. 5.

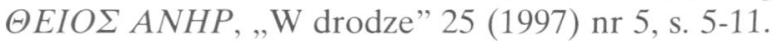

Apostołowie, „Pielgrzym” 9 (1998) nr 1, s. 4-5.

Jeszcze raz o ksiazze katolickiej, ,Niedziela” (warszawska) 61 (1998) nr 23, s. 7. Nie lubiana asceza (rozmowa z G. Idzikiem), „Niedziela” 41 (1998) nr 14, s. 10. Ottarzewskie święcenia, PK (1998) nr 21 (edycja warszawska).

Smutne myśli po pięknych targach ksiażki, „Niedziela” 41 (1998) nr 19, s. 18. Święty Jakub Alfeuszowy, Święty Filip, „Pielgrzym” 9 (1998) nr 8, s. 4-5.

Święty Piotr (1), „Pielgrzym” 9 (1998) nr 2, s. 3.

Święty Piotr (2), ,Pielgrzym” 9 (1998) nr 3, s. 4-5.

Święty Maciej, „Pielgrzym” 9 (1998) nr 10, s. 4.

Warto przeczytać; rubryka w: „Niedziela” 41 (1998): W. Linke, Nienawidzili go, ponieważ mówił prawdę, 41 (1998) nr 23, s. 9; D. Rops, Ksiądz Wincenty, 41 (1998) nr 25, s. 19; M. Zięba, Niezwykty pontyfikat, 41 (1998) nr 26, 10; J. Pałyga, Rwanda: czas apokalipsy, czas nadziei, 41 (1998) nr 27, s. 10; J. Ratzinger, Moje życie. Wspomnienia z lat 1927-1977, 41 (1998) nr 46A, s. 12.

Apostołowie, „Posłaniec Serca Jezusowego” (Chicago) 83 (1999) nr 10, 11-13. Jasny promyk dziecinstwa (1) „Sygnaturka” (czasopismo parafii Porąbka) 1998, nr 24; 1999 nr 25.

Legenda o Bożym Narodzeniu, „Inspiracje” 8 (1999) nr 8 (62), s. 12-16.

Medytacje nad obrazem Rembrandta, „Laetare. Kwartalnik wydawany przez Wyższe Metropolitalne Seminarium Duchowne w Warszawie" 1999, nr 4-5, s. $13-17$.

Nasi bracia, chrześcijanie Wschodu (1). Początki chrześcijaństwa w Gruzji, „Pielgrzym” 10 (1999) nr 16, s. 6.

Nasi bracia, chrześcijanie Wschodu (2). W walce z pogaństwem, „Pielgrzym” 10 (1999) nr 17, s. 6.

Nasi bracia, chrześcijanie Wschodu (3). Męczeństwo św. Szuszanik, „Pielgrzym" 10 (1999) nr 18, s. 7.

Nasi bracia, chrześcijanie Wschodu (4). Między mazdaizmem a islamem, „Pielgrzym” 10 (1999) nr 19, s. 6.

Nasi bracia, chrześcijanie Wschodu (5). Piotr Iberyjski, „Pielgrzym” 10 (1999) nr 20, s. 6. 
Nasi bracia, chrześcijanie Wschodu (6). Gruzja poza granicami Gruzji, „Pielgrzym" 10 (1999) nr 21, s. 6.

Nasi bracia, chrześcijanie Wschodu (7). Historia o Barlaamie i Jozafacie, „Pielgrzym” 10 (1999) nr 22, s. 6.

Nasi bracia, chrześcijanie Wschodu (8). Gruzińskie kwiatki św. Franciszka, „Pielgrzym” 10 (1999) nr 23, s. 6.

Rozwazania adwentowe, ,Inspiracje” 8 (1999) nr 7 (61) s. 35-36.

U początków chrześcijaństwa byt list, z ks. prof. M. Starowieyskim rozmawiają

J. Kliś - T.J. Żołciński, „Poczta Polska” 6 (1999) nr 45, s. 16-17; nr 46, s. 16-17.

Chrześcijanie i poganie, „Inspiracje” 9 (2000) nr 1-3, s. 63-65.

Legenda Bozego Narodzenia, „Powściągliwość i Praca” 51 (2000) nr 12, s. 11-13.

Nasi bracia, chrześcijanie Wschodu (9). Początki chrześcijaństwa w Armenii, „Pielgrzym” 11 (2000) nr 3, s. 7.

Nasi bracia, chrześcijanie Wschodu (10). Początki chrześcijaństwa w Armenii, Wiek V, „Pielgrzym” 11 (2000) nr 6, s. 7.

Nasi bracia, chrześcijanie Wschodu (11). Początki chrześcijaństwa w Armenii, Literatura, „Pielgrzym” 11 (2000) nr 8, s. 7.

Piekielne kompromisy [tytuł zmieniony przez redakcję, Autor przygotował tekst zatytułowany: Piekielne kompromitacje], w: Puste piekło, Warszawa 2000, 210-213.

Piekielne pytania, w: Puste piekło, Warszawa 2000, 203-205.

Zagłaskana teologia, „Więź” 63 (2000) nr 10, 69-80.

Legenda Bożego Narodzenia cd., „Powściągliwość i Praca”, 52 (2001) nr 1, s. $24-25$.

Moja Sardynia, „Powściągliwość i Praca” 52 (2001) nr 5, s. 14-16; tamże 52 (2001) nr 7-8, s. 20-21, 50-52.

Szkoła wytrwania, „List” 17 (2001) nr 8, s. 33-35.

Wędrówki angielskie. Chrześcijanie i poganie, „Powściągliwość i Praca” 52 (2001) nr 11, s. 14-16.

Wędrówki angielskie. Sejmik patrologów, „Powściągliwość i Praca” 52 (2001) nr 10, s. 9-11.

Wędrówki angielskie. Windsdor i Eton, „Powściągliwość i Praca” 52 (2001) nr 12, s. 10-12.

Odbudować mosty: kryzys kultury chrześcijańskiej i seminarium, „W drodze” 30 (2002) nr 9, s. 65-76.

O książce katolickiej myśli kilka : przed targami książki katolickiej, „W drodze” 31 (2003) nr 4, s. 35-45.

Ormiański męczennik, „Powściągliwość i Praca” 53 (2002) nr 1, s. 24-26.

W kręgu soborów, „Pielgrzym” 13 (2002) nr 11, s. 6.

Apokryfy, „Powściągliwość i Praca” 54 (2003) nr 4, s. 26-27. 
Dlaczego Kościoły Wschodnie, „Pielgrzym” 14 (2003) nr 15, s. 24.

Dziedzictwo Soboru Chalcedońskiego (1) - Koptowie, „Pielgrzym” 14 (2003) nr 8, s. 23-24.

Dziedzictwo Soboru Chalcedońskiego (2) - Melkici, „Pielgrzym” 14 (2003) nr 9, s. 24.

Dziedzictwo Soboru Chalcedońskiego (3) - Kościoły Syryjskie, „Pielgrzym” 14 (2003) $\mathrm{nr} 10$, s. 22-23.

Dziedzictwo Soboru Chalcedońskiego (4) - Ormianie, „Pielgrzym” 14 (2003) nr 11, s. 23-24.

Dziedzictwo Soboru Chalcedońskiego (5) - Etiopczycy, „Pielgrzym” 14 (2003) nr 12 , s. 24.

Dziedzictwo Soboru Efeskiego(1) - Kościół Chaldejski, „Pielgrzym” 14 (2003) nr 6, s. 23-24.

Dziedzictwo Soboru Efeskiego(2) - Kościoły w Indiach, „Pielgrzym” 14 (2003) nr 7, 24.

Kościoły przedchalcedońskie (1), „Pielgrzym” 14 (2003) nr 3, s. 24.

Kościoty przedchalcedońskie (1). Prawowierni, „Powściągliwość i Praca” 54 (2003) $\mathrm{nr} 7-8$, s. 33.

Moja Italia. Campo Verano, „Pielgrzym” 14 (2003) nr 25, s. 22-23.

Moja Italia. Pani Karla (1), „Pielgrzym” 14 (2003) nr 25, s. s. 22 i 24.

Mozaika Kościołów Wschodu, „Pielgrzym” 14 (2003) nr 13, s. 24.

Rzecz o eschatologii, „Pielgrzym” 14 (2003) nr 17. s. 18.

Sobory efeski i chalcedoński (2), „Pielgrzym” 14 (2003) nr 4, s. 24.

Sobór Watykański II, „Pielgrzym” 14 (2003) nr 14, s. 24.

Starożytność chrześcijańska (2). Sobory Efeski i Chalcedoński, „Powściągliwość i Praca” 54 (2003) nr 9, s. 21-22.

Starożytność chrześcijańska (3). Maronici, „Powściągliwość i Praca” 54 (2003) nr 10, s. 22.

Starożytność chrześcijańska (4). Kościót chaldejski, „Powściągliwość i Praca” 54 (2003) nr 11, s. 23.

Starożytność chrześcijańska (5). Kościoły w Indiach, „Powściągliwość i Praca” 54 (2003) nr 12, s. 18.

U korzeni chrześcijańskiej Europy, „Pielgrzym” 14 (2003) nr 16, s. 24.

Zawsze wierni - maronici (3), „Pielgrzym” 14 (2003) nr 5, 24.

Campo Verano, GN 81 (2004) nr 44.

„Moc Boża nie cierpi bezczynności” (o ks. prałacie J. Januszu), „Wołanie z Wołynia" 2004, nr 6, s. 24-29.

Moja Italia. Dwie wille - Villa Adriana, Villa d'Este, „Pielgrzym” 15 (2004) nr 2, s. 22 i 24.

Moja Italia. Elba nie tylko napoleońska, „Pielgrzym” 15 (2004) nr 5, s. 23-24. Moja Italia. Mentorella, „Pielgrzym” 15 (2004) nr 3, s. 23-24.

Moja Italia. Pani Karla (2) „Pielgrzym” 15 (2004) nr 1, s. 24. 
Moja Italia. Pani Karla (3) Dwie wille - Villa Adriana, Villa d'Este, „Pielgrzym” 15 (2004) nr 2, s. 22 i 24.

Moja Italia. W Toskanii, „Pielgrzym” 15 (2004) nr 4, s. 23-24.

Starożytność chrześcijańska (6). Koptowie, „Powściągliwość i Praca” 55 (2004) nr 1, s. 22.

Starożytność chrześcijańska (7). Melkici, „Powściągliwość i Praca” 55 (2004) nr 2, s. 6.

Starożytność chrześcijańska (8). Kościót syryjski, „Powściągliwość i Praca” 55 (2004) $\mathrm{nr} \mathrm{3,} \mathrm{s.} 18$.

Starożytność chrześcijańska (9). Ormianie, „Powściągliwość i Praca” 55 (2004) nr 5, s. 18.

Starożytność chrześcijańska (10). Etiopczycy, „Powściągliwość i Praca” 55 (2004) nr 6, s. 20.

Starożytność chrześcijańska (11). Dziedzictwo Kościołów Wschodu, „Powściągliwość i Praca” 55 (2004) nr 7-8, s. 26.

Starożytność chrześcijańska (12). Bohaterscy świadkowie, „Powściągliwość i Praca" 55 (2004) nr 9, s. 24.

Biedny św. Joachim, biedna św. Anna, „Powściągliwość i Praca” 51 (2005) nr 11, s. $20-21$.

Błogosławieństwo pokusy, „List” 21 (2005) nr 10, s. 41.

Dlaczego apoftegmaty Ojców Pustyni?, „List” 21 (2005) nr 9, s. 35.

Józef i Maryja, „Powściągliwość i Praca” 51 (2005) nr 12, s. 6-7.

Kilka myśli o jednym pontyfikacie, GN 82 (2005) nr 17, s. 18-19.

Konieczność wytchnienia, „List” 21 (2005) nr 12, s. 41.

Legendarny świat apokryfów (1), „Powściągliwość i Praca” 51 (2005) nr 10, s. 20.

Legendarny świat apokryfów (2), „Powściągliwość i Praca”, 51 (2005) nr 11, s. 20.

Ludzkie pytania, „List” 21 (2005) nr 11, s. 41.

Pochwała codzienności, „List” 21 (2005) nr 9, s. 36.

Bojaźń Boża początkiem mądrości, „List” 22 (2006) nr 2, s. 41-42.

Cud Papieskiego odejścia, „Powściągliwość i Praca”, 57 (2006) nr 5, s. 4-5.

Dwie zdumiewające rzeczy, „List” 22 (2006) nr 11, s. 50.

Gościnność, „List” 22 (2006) nr 12, s. 49.

Jak budować dom, „List” 22 (2006) nr 6, s. 51.

Jasna strona ludzkości, „List” 22 (2006) nr 5, s. 51.

Legendarny świat apokryfów, PrzKat 96 (2006) nr 19, s. 18-19.

Łagodność, Żywy przykład, „List” 22 (2006) nr 4, s. 50.

Nie zgasi tlącego się knotka, „List” 22 (2006) nr 1, s. 41.

Po zmartwychwstaniu: Boża sprawiedliwość, „List” Maryi, „Powściągliwość i Praca" 57 (2006) nr 5, s. 16-17.

Proces Jezusa i cierpienia Maryi, „Powściągliwość i Praca” 57 (2006) nr 3, s. 16-17. 
Poznaj samego siebie, „List” 22 (2006) nr 10, s. 49.

Prosta wiara, „List” 22 (2006) nr 3, s. 41

Przede wszystkim dobro, „List” 22 (2006) nr 9, s. 51.

Stowa Jezusa, „Powściągliwość i Praca”, 57 (2006) nr 6.

Wielkanoc: Zstapił do piekiet, Zmartwychwstanie i historia pierwszego świadka, tamże 57 (2006) nr 4, s. 10-11.

Wielka noc, „Powściągliwość i Praca”, 57 (2006) nr 4, s. 10-11.

Wielki spór i pasterze, „Powściągliwość i Praca” 57 (2006) nr 2, s. 14-15.

Wielobarwny świat apokryfów (rozm. przepr. M. Terlikowska), „Ozon” 2006, nr 20, s. 50-53.

Wśród apokryfów i Ojców Kościoła, (rozm. przepr. Sławomir Mizerski), „Polityka" 2006, nr 25, dod. Niezbędnik Inteligenta, s. 24-28.

Zstapit do piekiet, PrzKat 96 (2006) nr 20, s. 17.

Żywy przykład, „List” 22 (2006) nr 4, s. 50. 